http://dx.doi.org/10.4314/jae.v16i2.14

\title{
Organic Farming as a Strategy for Climate Change Adaptation and Mitigation in Sub-Saharan Africa: Implications for Policy
}

\author{
R. N. Mgbenka \\ Department of Agricultural Extension, Faculty of Agriculture, University of Nigeria, \\ Nsukka, Nigeria. \\ E-mail Address: amakamg@yahoo.com
}

\begin{abstract}
The study focuses on organic farming (OF) as a strategy for climate change adaptation and mitigation in sub-Saharan Africa. The potential contribution of OF to mitigation of climate change lies in the following: its $\mathrm{CO}_{2}$ sequestration in the soil and careful management of nutrients and hence, the reduction of $\mathrm{N}_{2} \mathrm{O}$ emissions from soils. For climate change adaptation, OF systems have a strong potential for building resilient food systems through farm diversification and building soil fertility with organic matter. In developing countries, OF offers alternatives to energy-intensive production inputs such as synthetic fertilizers which are limited for poor rural populations by rising energy prices. Also, OF systems achieve equal or even higher yields in developing countries, as compared to the current conventional practices. This provides a considerable option for food security and sustainable livelihoods for the rural poor in times of climate change. The region under review is experiencing some challenges as regards OF development such as poor local marketing, low level of organic certification, little information on OF, little or no policies to safeguard OF activities, little private sector involvement and lack of technical assistance. The study recommends that in order to promote and accelerate sustainable OF in the sub-Saharan Africa, all stakeholders and governments must as a matter of policy establish departments of organic agriculture in higher institutions of learning, train extension workers in OF practices, disseminate emerging indigenous OF knowledge, skills, technologies and crop varieties. It also highlights the need to build on indigenous knowledge in response and in partnership with farmers, proper funding of OF researches, and promote development of local and regional markets for organic products.
\end{abstract}

Key words: Organic farming, climate change, adaptation, mitigation, subSaharan Africa 


\section{Introduction}

Climate change is the increase in temperatures and changes in weather patterns created by carbon and other greenhouse gas emissions (Sandberg and Sandberg, 2010). According to Scialabba and Muller-Lindenlauf (2010), the emission reduction potential by non-use of mineral fertilizers is calculated to be about $20 \%$ and the compensation potential by carbon sequestration to be about $40-72 \%$ of the world's current annual agricultural GHG emissions. The total mitigation potential of organic sustainable food system is $29.5 \%$ of global GHG emission and $16.5 \%$ of energy use, the largest components coming from carbon sequestration and reduced transport from re-localized food systems. Organic farming (OF) removes 7,000 Pounds of $\mathrm{CO}_{2}$ from the atmosphere per acre every year (McDermott, 2009).

Modern industrial agriculture of the Green Revolution contributes to a great deal to climate change. It is the main source of the potent greenhouse gases (GHG), nitrous oxide and methane. It is heavily dependent on the use of fossil fuels and contributes to the loss of carbon to the atmosphere (Institute of Science in Society (ISIS) Report, 2008). The $4^{\text {th }}$ assessment report of the Intergovernmental Panel on Climate Change (IPCC) identifies Africa, particularly sub-Saharan Africa, as extremely vulnerable due to the fact that these countries' economies are highly dependent on natural resources and rainfed agriculture, and they generally have a low level of adaptive capacity (Huq, 2008).

Organic farming is a holistic production management system which promotes and enhances agro-ecosystem health, including biodiversity, biological cycles, and soil biological activity (Muller, 2009). Organic farming offers a sustainable solution to many environmental and food security problems in sub-Saharan Africa. It emphasizes recycling techniques and low external input and high output strategies. It is based on enhancing soil fertility and diversity at all levels and makes soils less susceptible to erosion and other climate change effects. Organic sustainable agriculture that localized food systems has the potential to mitigate nearly $30 \%$ of global GHG emissions and save one-sixth of global energy use (Mae-Wan Ho and Lim Li Ching, 2008). Consequently, the special benefits of OF can be great mitigation and adaptation potential, particularly with regard to soil organic matter fixation, soil fertility and water-holding capacity, increasing yields in areas with medium to low-input agriculture and in agroforestry. It also enhances farmers' adaptive capacity.

The paper therefore reviews OF as a strategy for climate change adaptation and mitigation in sub-Saharan Africa; examines the sustainable farming systems, cropland management, grassland and livestock management under OF, assesses challenges as regards OF development, and also makes policy recommendations. The paper relied on current literature and observations on climate change. 


\section{Sustainable farming systems}

Over the years, many countries in sub-Saharan Africa have suffered severely due to disasters caused by climate change. In 2007, for example, parts of Africa suffered severe drought while floods on much of the continent destroyed roads and buildings and wiped out millions of hectares of farmland (Spore, 2008). Some farming systems that help in climate change adaptation and mitigation include:

\section{Shifting cropping patterns}

Conservation agriculture, which involves minimal disturbance, can improve water use efficiency, carbon sequestration and the capacity to withstand weather stresses. As weather pattern shift, producers changed the times they plant and the crops they grow; for example, in South Africa, farmers started delaying planting of maize to take account of changing rainfall patterns (Spore, 2008). A number of climate-resilient crop varieties have reached farmers' fields and more are being developed (Benhin, 2008). Using traditional technologies and indigenous knowledge farmers often select crop combinations that will survive harsh conditions such as maize-beans, cowpea-sorghum and millet-groundnut mixtures.

\section{Crop diversification}

By abstaining from synthetic inputs, OF systems cannot but adapt to local environmental conditions. Therefore, species and varieties are chosen for their adaptability to the local soil, and climatic conditions and their resistance to local pests and diseases. Organic farmers prefer not to use uniform crops and breeds and opt for more robust traditional species, which they tend to conserve and develop. Farmers in Africa adapt to drought by switching to different crop varieties with shorter cycles and better resistance to water stress (Luis, 2008). Another option will be to adopt water conservation practices that favour infiltration and soil water storage, and combat evaporation from the soil (Pereira, 2008). Spore (2008) advocates that farmers focus on stress-tolerant rather than just high-yielding varieties of crop. Diverse cropping systems in developing countries do not only rely on cash crops but also on food crops for household consumption (FAO, 2008). Scialabba and Muller-Lindenlauf (2010) noted that the diversification of cropping systems also make more efficient use of available nutrients with improved productivity and economic performance which is of high importance in times of limited nutrients and financial constraints.

\section{Integrated livestock production}

International Federation of Organic Agricultural Movements (IFOAM) advocates for harmonious balance between crop production and animal husbandry. To be successful, OF must integrate plant and livestock production to the extent possible to optimize nutrient use and recycling. Currently, half of the world's pork 
production originates from industrial landless systems, and for poultry meat this share amounts to over 70\% (Steinfeld, Gerber, Wassenaar, Rosales, et al., 2006). Manure input is tailored to plant uptake capacities, an aspect which is recommended as a mitigation strategy by the IPCC in order to reduce $\mathrm{N}_{2} \mathrm{O}$ emissions and leaching (Smith, 2007). However, Methane and $\mathrm{N}_{2} \mathrm{O}$ from manure account for about 7\% of the agricultural GHG emissions (Smith, Martino, Cai, Gwary, et al., 2007). Methane emissions predominantly occur in liquid manure systems, while $\mathrm{N}_{2} \mathrm{O}$ emissions are higher in solid manure systems and on pastures. Measures leading to a reduction of methane emissions from manure often increase emissions of $\mathrm{N}_{2} \mathrm{O}$ and vice versa (Paustian, Babcock, Hatfield, Lal, et al., 2004). But methane emissions from liquid manure can be reduced nearly to zero by fermenting the slurry in biogas plants, which would have the positive side effect of generating renewable energy and is in line with organic principles. There is certainly limited mitigation potential for most animals worldwide for $\mathrm{N}_{2} \mathrm{O}$ (Smith, Martino, Cai, Gwary, et al., 2007) but mitigation can occur in integrated livestock management. Case study calculations showed that the methane emissions from milk and beef production can be reduced more than $20 \%$ by keeping double-use breeds (i.e., for milk and meat production) (Rosenberger, Go" tz, K.-U., Dodenhoff, Krogmeier, et al., 2009). On pastures, avoidance of overgrazing prevents land degradation and high soil carbon losses (Conant and Paustian, 2002).

\section{Restoration of degraded land}

There is much scope for mitigating climate change and reversing the damages through making agriculture and the food system as a whole sustainable. Organic farming practices such as crop rotation, cover crops, manuring and application of organic amendments are recommended strategies to restore degraded soils and hence improve the livelihoods of rural populations affected by climate change in sub-Saharan Africa where up to $70 \%$ of the land in dry areas is assumed to be degraded (Dregne and Chou, 1994). In the Tigray Province, one of the most degraded parts of Ethiopia, agricultural productivity was doubled by soil fertility techniques over 1 million hectares through agroforestry, application of compost and introduction of leguminous plants into the crop sequence. Restoration of degraded land not only offers income opportunities for rural populations but also has a huge mitigation potential by increasing soil carbon sequestration. The total mitigation potential by restoration of degraded land is estimated as $0.15 \mathrm{Gt}$ (technical potential up to USD 20 per $\mathrm{t}$ of carbon) and up to $0.7 \mathrm{Gt}$ (physical potential) (Smith, Martino, Cai, Gwary, et al., 2008).

\section{Cropland management}

Cropland management involves series of climate change mitigation practices aimed at reducing the sources or enhancing the sinks of GHG. As nitrogen is far more limited in organic systems, there is a strong incentive to avoid losses and enhance soil fertility. Furthermore, there is a need to reduce the risk of pest and diseases by preventive measures. According to Scialabba, et al. (2010) the most 
important measure for achieving these aims is a crop rotation, including catch and cover crops and intercropping. Mitigation strategies in OF also include improved crop and grazing land management to increase soil carbon storage; restoration of cultivated peaty soils tillage, cover cropping and recycling of bio-solids. Others include the following:

\section{Reduction of nitrous oxides emission}

Nitrous oxide emissions are the most important source of agricultural emissions, which contribute $38 \%$ of agricultural GHG emissions (Smith, Martino, Cai, Gwary, et al. 2007). There are direct and indirect emissions through livestock production, $\mathrm{NH}_{3}$ and $\mathrm{NO}_{3}$ emissions, nitrogen leakage into rivers and coastal zones, etc. In organic systems, the nitrogen input to soils, and hence the potential nitrous oxide emissions, are reduced. Catch and cover crops extract plant-available nitrogen unused by the preceding crop and keep it in the system. Therefore, they further reduce the level of reactive nitrogen in the topsoil which is the main driving factor for $\mathrm{N}_{2} \mathrm{O}$ emissions (Ruser, Flessa, Schilling, Beese, et al., 2001). A study from The Netherlands comparing 13 organically and conventionally managed farms showed lower levels of soluble nitrogen in the organically managed soils (Diepeningen, de Vos, Korthals, and van Bruggen, 2006). The peaks in $\mathrm{N}_{2} \mathrm{O}$ can be mitigated by enhanced aeration of the top soil. In compacted soils, the risk of nitrous oxide emissions is higher. Organic management practices facilitate a lower bulk density, enhancing soil aeration. Low aeration is also a reason for partly higher risk of $\mathrm{N}_{2} \mathrm{O}$ emissions in no-tillage systems (Rochette, Angers, Chantigny and Bertrand, 2008). The highest risk for $\mathrm{N}_{2} \mathrm{O}$ emissions in organic farms is the incorporation of legumes, which are the main nitrogen source for organic farms. But the average of $\mathrm{N}_{2} \mathrm{O}$ emissions over the whole crop rotation was lower for the organic farm, as compared to the conventional system (Rochette, et al., 2008).

\section{Organic farming and carbon sequestration}

Smith, Martino, Cai, Gwary, et al., (2007) reported that another mitigation effect of catch and cover crops, intercropping and manure is an increased carbon sequestration in the soil. Several field studies have proved the positive effect of OF practice on soil carbon pools (Fliessbach, Oberholzer, Gunst, and Mader, 2007). In Switzerland, a long-term trial biodynamic system showed a stable carbon content, while a carbon loss of $15 \%$ in 21 years was measured for the compared conventional system (Scialabba et al., 2008). In the USA, a field trial showed a fivefold higher carbon sequestration in the organic system (i.e., $1218 \mathrm{~kg}$ of carbon per hectare per year) in comparison with conventional management (Pimentel, Hepperly, Hanson, Douds, et al., 2005).

The sequestration potential of organic croplands was calculated to be $0.9-2.4 \mathrm{Gt}$ $\mathrm{CO}_{2}$ per year (which is equivalent to an average sequestration potential of about 0.2-0.4 t C per hectare per year for all croplands) (Niggli, Rounsevell, Smith, and Verhagen, 2009), which represents $15-47 \%$ of total annual agricultural GHG emissions (Smith, Martino, Cai, Gwary, et al., 2007). Some practices currently 
discussed for their high sequestration potential such as no-tillage are so far poorly applicable in organic systems. However, no-tillage is difficult in OF systems because the accompanied insurgence of weeds cannot be faced with herbicides, as in conventional systems, but only by mechanical weed control, if affordable.

It is necessary to consider the fact that in assessing soil management impact on GHG emissions there is trade-off between carbon sequestration and $\mathrm{N}_{2} \mathrm{O}$. Conventional no tillage systems perform well in terms of carbon sequestration but can increase $\mathrm{N}_{2} \mathrm{O}$ emissions (Smith, and Conen, 2004). For developing countries, there are still few research data available concerning soil carbon sequestration rates and $\mathrm{N}_{2} \mathrm{O}$ emissions (Scialabba, et al., 2010).

Most of the soil-sequestered carbon is stored as soil organic matter. In different long-term field trials, organic matter content in organically managed soils was higher. Soil organic matter has positive effects on the water-holding capacity of the soil (Scialabba, et al., 2010). A higher water-holding capacity strengthens the resilience to droughts and reduces the risk of floods, which are both more likely to increase with climate change. The need for irrigation is reduced, which has an additional adaptation and mitigation effect. Furthermore, soil organic matter enhances the nutrient buffer capacity and the microbial activity, both strengthening soil fertility (Fan, Stewart, Payne, Yong, et al., 2005).

\section{Paddy production}

Neue, Wassmann, Lantin, Alberto, et al. (1996) identified another agricultural GHG source influenced by cropping systems which is methane from paddy rice fields. This accounts for $11 \%$ of global agricultural GHG emissions. The main influencing factors are cultivars, organic amendments and drainage. While organic amendments increase emissions, drainage reduces emissions (Yang and Chang, 2001). Organic systems add more organic amendments but adding amendments in times of drainage could avoid higher emissions. Generally, there are adverse effects of organic paddy production on methane emissions due to organic fertilization, while emission compensation measures (such as drainage) are not mandatory. One promising approach could be the combination of organic practices with resource-saving systems as the 'system of rice intensification' (SRI), where soils are kept un-flooded most of the growing period and hence methane emissions are significantly reduced (Uphoff, 2002).

\section{Livestock management}

\section{Methane emission from livestock}

In 2007, FAO's Deputy-General Alexander Muller estimated that livestock keeping caused $37 \%$ of methane emissions and $9 \%$ of carbon dioxide $\left(\mathrm{CO}_{2}\right)$ output and that it also used $8 \%$ of the world's water (Spore, 2008). The challenge is to limit its impact on the environment while satisfying the growing demand for its products (meat, milk and eggs). IPCC (2007) reported that one of the most important sources of GHG emissions from agriculture are the methane emissions from 
enteric fermentation, which accounts for $4-5 \%$ of the global anthropogenic GHG emissions. The quantity of methane emitted per product unit depends on the animal diet and the cow breed's performance.

High milk yields per cow reduce emissions per product unit. High energy feedstuff (e.g., grains and soya) can reduce emissions because methane emissions mainly derive from the digestion of fiber from roughage (Pelchen, 1996). In developed countries, organic management usually achieves lower milk yields per cow than conventional production (Bradley, 2007). The main reason is a more roughagebased ration with low concentrate supply. However in developing countries, where two thirds of the enteric methane emissions occur, organic systems achieve higher milk yields, as more careful management improves the relatively low performance of traditional systems (Pretty and Hine, 2001).

In organic systems, ruminants are kept to make productive use of fodder legumes, which play an important role as nitrogen source in organic crop rotation. High livestock performance is generally achieved by feeding high-energy crops, which neglects the unique ability of ruminants to digest roughage. Using crops for feed rather than food poses substantial challenges to food security; currently, onethird of the world's cropland is used to produce animal feed (Steinfeld, Gerber, Wassenaar, Rosales, et al., 2006). Furthermore, high energy concentration in animal diets if not managed very carefully, can lead to rumen acidification and secondary inflammations, which is a cause of animal illness (PLaizier, Krause, Gozho, and McBride, 2009). Therefore, from an organic perspective, there are severe constraints to mitigating methane emissions from enteric fermentation by shifting to a high-energy diet by feeding higher amounts of concentrates. The objective of organic livestock management, though not yet achieved, is to create a nearly closed nutrient cycle whereby feed is supplied on-farm. While integration and disintensification are attempted (to different degrees) everywhere in organic livestock systems, there is an increasing awareness of the need to optimize the productivity of roughage with more research and development. Methane emissions from organic livestock systems can be reduced by about 10\% (under European conditions) through reduced animal replacement rates (Muller-Lindenlauf, 2009). Also, stress resistance (an important factor under climate change conditions) and longevity are among the most important traits of organic breeding (Van Diepen, McLean and Frost, 2007).

\section{Carbon sequestration in livestock management}

Pastures are the favored feeding strategy for organic cattle. Therefore, organic livestock management is an option for maintaining grasslands, which have a high carbon sequestration potential (Smith, Martino, Cai, Gwary, et al., 2007). Combined with a limited livestock density to prevent overgrazing, organic grassland farming could be a way to optimize carbon sequestration in grasslands (Rice and Owensby, 2001). 
The global carbon sequestration potential by improved pasture management practices was calculated to be $0.22 \mathrm{t} \mathrm{C}$ per ha per year. Assuming $0.2 \mathrm{t} C$ per ha per year for OF practices, the total carbon sequestration potential of the world's grassland would be $1.4 \mathrm{Gt}$ per year at the current state, which is equivalent to about $25 \%$ of the annual GHG emissions from agriculture (Niggli, Niggli, Rounsevell, Smith, et al., 2009).

\section{Benefits of organic farming towards climate change mitigation and adaptation}

Organic farming has much to offer in both mitigation of climate change through its emphasis on closed nutrient cycles. It is also a particularly resilient and productive system for adaptation strategies. Lim Li Ching of Third World Network (TWN), (undated), summarized the benefits of OF regarding climate change as follows:

- Organic farming has considerable potential for reducing emissions of GHG. OF in general requires less fossil fuel per hectare and $\mathrm{kg}$ of produce due to the avoidance of synthetic fertilizers. It aims at improving soil fertility and nitrogen supply by using leguminous crops, crop residues and cover crops.

- The enhanced soil fertility leads to stabilization of soil organic matter and in many cases to a sequestration of carbon dioxide in the soil, increased soil's water retention capacity, ability to withstand climate change and effective reduction of soil erosion which is a source of $\mathrm{CO}_{2}$ losses.

- Organic farming can contribute substantially to agro forestry production systems because OF include extensive field margins, hedges, trees or bushes, woodlands, waterways, wetlands and extensive grasslands which are useful to reduce erosion, which is expected to be aggravated by climate change.

- Organic systems are highly adaptive to climate change due to the application of traditional skills and farmers' knowledge, soil fertility-building techniques and a high degree of diversity. 
TABLE 1

Mitigation potentials of organic farming

\begin{tabular}{|c|c|c|c|}
\hline $\begin{array}{l}\text { Direct emissions } \\
\text { from } \\
\text { Agriculture }\end{array}$ & $\begin{array}{l}\text { Share of total } \\
\text { anthropogenic } \\
\text { GHG emissions } \\
10-12 \%\end{array}$ & $\begin{array}{l}\text { Impacts of } \\
\text { optimized } \\
\text { organic } \\
\text { management }\end{array}$ & Remarks \\
\hline $\mathrm{N}_{2} \mathrm{O}$ from soils & $4.2 \%$ & Reduction & $\begin{array}{l}\text { Higher nitrogen use } \\
\text { efficiency }\end{array}$ \\
\hline $\begin{array}{l}\mathrm{CH} 4 \text { from enteric } \\
\text { Fermentation }\end{array}$ & $3.5 \%$ & Opposed effects & $\begin{array}{l}\text { Increased by lower } \\
\text { performance and } \\
\text { lower energy concentration in } \\
\text { the diet } \\
\text { but reduced by lower } \\
\text { replacement rate } \\
\text { and multi-use breeds }\end{array}$ \\
\hline Biomass burning & $1.3 \%$ & Reduction & $\begin{array}{l}\text { Burning avoided according to } \\
\text { organic standards }\end{array}$ \\
\hline Paddy rice & $1.2 \%$ & Opposed effects & $\begin{array}{l}\text { Increased by organic } \\
\text { amendments but lowered } \\
\text { by drainage and aquatic } \\
\text { weeds }\end{array}$ \\
\hline Manure handling & $0.8 \%$ & Equal & $\begin{array}{l}\text { Reduced methane emissions } \\
\text { but no effect } \\
\text { on N2O emissions }\end{array}$ \\
\hline $\begin{array}{l}\text { Direct emissions } \\
\text { from forest } \\
\text { clearing for } \\
\text { agriculture } \\
\text { Indirect } \\
\text { emissions }\end{array}$ & $12 \%$ & Reduction & $\begin{array}{l}\text { Clearing of primary } \\
\text { ecosystems restricted }\end{array}$ \\
\hline Mineral fertilizers & $1 \%$ & Totally avoided & $\begin{array}{l}\text { Prohibited use of mineral } \\
\text { fertilizers }\end{array}$ \\
\hline Food chain & $?$ & (Reduction) & $\begin{array}{l}\text { Inherent energy saving but } \\
\text { still inefficient } \\
\text { distribution systems }\end{array}$ \\
\hline $\begin{array}{l}\text { Carbon } \\
\text { sequestration } \\
\text { Arable lands } \\
\text { Grasslands }\end{array}$ & & $\begin{array}{l}\text { Enhanced } \\
\text { Enhanced }\end{array}$ & $\begin{array}{l}\text { Increased soil organic matter } \\
\text { Increased soil organic matter }\end{array}$ \\
\hline
\end{tabular}

Source: Scialabba and Muller-Lindenlauf (2011) 


\section{Challenges of organic farming in sub-Saharan Africa}

According to Adeoluwa, (2010), some challenges faced by some developing countries concerning OF include:

Poor local marketing is one big challenge to practicing OF. Organic farming thrives with efficient marketing systems. Generally, many farmers have been discouraged from going into organic production because of the lack of or poorly developed local markets for organic products. For example, majority of the organic farmers in West Africa focus on export markets but cannot afford third party certification which makes it difficult to get good premiums from the sale of their organic products (Adeoluwa, 2010). However, a certified organic farm in Nigeria (Dara/Eurobridge Farm, Ogun State) currently sells its organic lemon grass tea (under the trade mark of Daradara Herbal Tea), Turmeric Cucuma Longa for food seasoning, Ofada Rice, Red Hibiscus for a local soft drink production (popularly known as Sobo in Nigeria), and other produce to the local market, (a situation many regard as under-maximization of the premium benefits in OF and export market (Kazeem, 2010).

Adeoluwa (2010) also identified low level of organic certification as one of the challenges. Third party certification in Africa is mostly used as a means of accessing foreign markets However, the majority of the farmers in West Africa cannot afford the costs of getting their farms certified through the third party system, hence the number of certified farms in the region is low

There is little information on OF activities in many of the countries in sub-Saharan Africa (IFOAM, 2004). Many Nigerian farmers for example, do not practice OF per excellence. Olabiyi, Okusanya, and Harris, (2008) reported that Nigerian farming system was perceived as "organic by default". Perhaps, more farmers would have become interested in OF if they had access to information showing how feasible it is to invest in the practice.

- One of the disturbing challenges that causes set back on OF is little or no polices to safeguard OF activities. Most national governments in West Africa have no policies in place to safeguard OF practices in their countries (Adeoluwa, 2010). Indiscriminate use of agrochemical and other synthetic inputs is not yet adequately recognized as a serious problem in the region.

- Sourcing of appropriate inputs for OF is another major constraint to the adoption of OF in West Africa. There is lack of appropriate inputs such as bio-fertilizer and bio-pesticides and information needed in OF production.

- Adeoluwa (2010) also noted poor private sector involvement in OF system in the region. The current level of involvement of the private sector in OF in West Africa is very low. In other places of the world, private firms invest heavily in production, processing and marketing of organic products. The resultant effects are increased activities and the expansion of the OF sector. 
Lack of technical assistance is one of the challenges of OF in the region (Adeoluwa 2010). In most sub-Saharan countries, there are inadequate OF service providers. Often, farmers need technical assistance in terms of agriculture operators in the region. Establishment of technical support structures, workshops and public awareness on OF focusing on benefits derivable from it as well as mass sensitization through posters, newsletters etc. is highly needed.

\section{Policy recommendations towards sustainable organic farming}

It is recommended by Mobilizing Regional Capacity Initiative (MRCI) (2010) that in order to promote and accelerate sustainable OF in sub-Saharan Africa, all stakeholders and government must:

- Set sustainable agriculture through organic practices as a priority,

- Review current policies and programmes, and remove disincentives to organic agriculture in, for example, subsidies on agrochemicals,

- Establish Department/Faculties of OF in higher institutions of learning especially the universities of agriculture and colleges of agriculture,

- Train extension workers in OF practices,

- Encourage farmer-to-farmer exchanges,

- Compile and disseminate emerging indigenous OF knowledge skills, technologies and crop varieties,

- Adequately and promptly fund OF research,

- Build on indigenous knowledge in response and in partnership with farmers; and promote development of local and regional markets for organic products.

Additionally, Oyesola, and Obabire (2011) proposed the following policy recommendations which emanated from a study they conducted in Nigeria:

- active involvement of youths and women in organic crop production

- improvement of information sources on OF, and enlightenments on various organic methods of weed, pest and disease control through the regular sources of information on OF.

- farmers should be motivated through credit facilities and discouragement of inOF in order to ensure sustainable production of food, since the farmers have a favourable perception towards OF. 


\section{Conclusion}

Different studies all over the world have proven that OF systems have an inherent potential to both reduce GHG emissions and to enhance carbon sequestration in the soil. Organic farming reduces emissions of greenhouse gases and enhances adaptation to climate change through sustainable farming systems such as shifting cropping patterns, crop diversification, integrated livestock production and restoration of degraded lands. Integration of livestock and arable production, the rule on organic farms, can reduce the global warming potential of food production. However, OF is not quite developed in the sub-Saharan Africa, hence farmers are faced with many challenges. In order to improve on OF in the region, many policies have been suggested for the governments, voluntary organizations, universities and farmers.

\section{References}

Adeoluwa, O. O. (2010). Organic agriculture and fair trade in West Africa, Food and Agriculture

Organization of the United Nations, Office of Knowledge Exchange, FAO Viale delle Terme di Caracalla, 00153 Rome, Italy, Pp.339-342.

Benhin, J. (2008). Climate change and agriculture in Africa: Impact Assessment and adaptation strategies. Earthscan/CEEPA/World Bank, pp.224 www.earthprint.com

Badgley, C., Moghtader, J., Quintero, E., Zakem, E., Chappell, M.J., Avile'sVa`quez,

K., Samulon, A., and Perfecto, I. (2007). Organic agriculture and the global food supply. Renewable Agriculture and Food Systems, 22:86-108.

Conant, R.T. and Paustian, K. ( 2002). Potential soil carbon sequestration in overgrazed grassland ecosystems. Global Biogeochemical Cycles, 16:90 pp190.9.

Dregne, H.E. and Chou, N.T. (1994). Global desertification dimensions and costs. In: H.E. Dregne (ed.). Degradation and Restoration of Arid Lands. Texas Technical University, Lubbock, USA.

Diepeningen, A.D., de Vos, O.J., Korthals, G.W., and van Bruggen, A.H.C. (2006). Effects of organic versus conventional management on chemical and biological parameters in agricultural soils. Applied Soil Ecology vol. 31, pp. 20-135.

Fan, T., Stewart, B.A., Payne, W., Yong, W., Luo, J., and Gao, Y.( 2005) . Longterm fertilizer and water availability effects on cereal yield and soil chemical properties in northwest China. Soil Science ofS America Journal vol.69, pp.842-855. 
Food and Agriculture Organisation of the United Nations (FAO)( 2008). Soaring Food Prices: Facts, Perspectives, Impacts and Actions Required. $\mathrm{HLC} / 08 / \mathrm{INF} / 1$. FAO, Rome, Italy.

FAOSTAT. (2009). FAO Statistical Database Domain on Fertilizers: Resource STAT-Fertilizers.

Food and Agriculture Organisation of the United Nations (FAO) Rome, Italy. Available at Web site http://faostat.fao.org/site/575/default. aspx\#anchor (accessed 7 October 2009).

Fliessbach, A., Oberholzer, H.R., Gunst, L., and Mader, P.( 2007). Soil organic matter and biological soil quality indicators after 21 years of organic and conventional farming.

Agriculture, Ecosystems and Environment, 118:273-284.

International Federation of Organic Agricultural Movements (IFOAM), (2004). Network building for lobbying in Africa. Compiled by Souleymane Bassoum, Rene Tokannou and Nuji Mutura. IFOAM, Bonn.

Inubushi, K., Sugii, H., Nishino, S., and Nishino, E. (2001). Effect of aquatic weeds on methane emission from submerged paddy soil. American Journal of Botany 88(6): 975-979.

Institute of Science in Society (ISIS), (2008). Mitigating climate change through organic agriculture and localized food systems. ISIS Report 31/1/08.

Intergovernmental Panel on Climate Change (IPCC). (2007). Synthesis report. In: O.R.D. Metz, P.R. Bosch, R. Dave, and L.A. Meyer (eds.). Fourth Assessment Report: Climate Change 2007. Cambridge University Press, Cambridge, UK.

Kazeem, O. (2010). Organic farming gets a boost in Nigeria. The Nation Newspaper, $25^{\text {th }}$ May, 2010. pp. 1-2.

Lim Li Ching, (undated). Organic farming and climate change. Third World Network, 131 Jalan

Macalister, $10400 \quad$ Penang, Malaysia. Email: twnet@po.jaring.my. ebsitea:www.twnside.org.sg, www.biosafety-info.net

Luis, S. P. (2008). Irrigation challenges. Spore, Climate change. Spore, CTA Special Issue- August, 2008. pp.9. http:spore.cta.int

McDermott, M., (2009). Use organic agriculture to fight climate change, EU official says :Tree Hugger, New York, NY, pp.1-2.

Mae-Wan Ho and Lim Li Ching (2008). Mitigating climate change through organic agriculture and localized food systems. ISIS Report 31/1/08. 
Mobilising Regional Capacity Initiative (MRCI) (2010). Sustainable organic agriculture development in West Africa, Association of African Universities (AAU) Aviation Road Extension, Airport Residential Area, Accra-North, Ghana.

Muller-Lindenlauf, M. (2009). Umweltwirkungen okologisch wirtschaftender

Milchviehbetriebe unterschiedlicher Fu" tterungsintensita " $t$ und Produktionsstruktur. PhD thesis, University of Bonn, Dr. Ko"ster, Berlin, Germany.

Niggli, U., Rounsevell, M.D.A., Smith, P., and Verhagen, J. (2009). Low Greenhouse Gas Agriculture: Mitigation and Adaptation Potential of Sustainable Farming Systems. FAO, Rome, Italy. Available at Web site ftp://ftp.fao.org/docrep/fao/010/ai781e/ai781e00.pdf (verified 15 October 2009).

Neue, H.U., Wassmann, R., Lantin, R.S., Alberto, M.C.R., Aduna, J.B., and Javellana, A.M. (1996). Factors affecting methane emission from rice fields. Atmospheric Environment vol.30, pp.1751-1754.

Olabiyi, T. I.; Okusanya, A. O. and Harris, P. J. C. (2008). Accessing the World Market for Organic Food Beverages from Nigeria. $16^{\text {th }}$ IFOAM Organic Congress, Modena, Italy, June 16-20, 2008. Archive at http://orgprints org/.

Oyesola, O. B. and Obabire, I. E. (2011). Farmers' perception of organic farming in selected Local Government Areas of Ekiti State of Nigeria. Journal of Organic Systems, vol.6(1), pp.5-6.

Paustian, K., Babcock, B.A., Hatfield, J., Lal, R., McCarl, B.A., McLaughlin, C., Mosier, A., Rice, C., Robertson, G.P., Rosenberg, N.J., Rosenzweig, C., Schlesinger, W.H., and Zilberman, D. (2004). Agricultural Mitigation of Greenhouse Gases: Science and Policy Options. CAST (Council on Agricultural Science and Technology) Report R141. Ames, IA, USA.

Pelchen, A. (1996). Dynamik von Methanemissionen landwirtschaftlicher Nutztiere unter dem

Einfluss verschiedener Fütterungssysteme-eine Modellbetrachtung zum Treibhauseffekt. PhD thesis, Humbolt-University, Berlin, Germany.

Pereira, L. S. (2008). Irrigation challenges. Spore, August 2008: Climate change, pp. 9.

Pimentel, D., Hepperly, P., Hanson, J., Douds, D., and Seidel, R. (2005). Environmental, energetic and economic comparison of organic and conventional farming systems, Bioscience,vol.55, pp.573-582.

Plaizier, J.C., Krause, D.O., Gozho, G.N., and McBride, B.W. 2009. Sub- acute ruminal acidosis in dairy cows: The physiological causes, incidence and consequences, The Veterinary Journal vol.176,pp. 21-31. 
Pretty, J. and Hine, R. (2001). Reducing Food Poverty with Sustainable Agriculture: A Summary of New Evidence. Final Report from the 'SAFE World' Research Project, University of Essex, Colchester, UK.

Rice, C.W. and Owensby, C.E. (2001). Effects of fire and grazing on soil carbon in rangelands. In: R. Follet, M.M. Kimble, and R. Lal (eds.). The Potential of U.S. Grazing Lands to Sequester Carbon and Mitigate the Greenhouse Effect. Lewis Publishers, Boca Raton, FL, USA. p. 323-342.

Rochette, P., Angers, D.A., Chantigny, M.H., and Bertrand, N. (2008). Nitrous oxide emissions respond differently to no till in loam and heavy clay soil. Soil Science Society of America Journal vol.72, pp.1363-1369.

Rosenberger, E., Go” tz, K.-U., Dodenhoff, J., Krogmeier, D., Emmerling, R., Luntz, B., and Anzenberger, H. (2004). U" berpru"fung der Zuchtstrategie beim Fleckvieh. Bayerische Landes anstalt fu" $r$ Landwirtschaft, Poing, Germany. Available at Web site http://www.lfl.bayern.de/itz/rind/09285/index. php (verified 20 October 2009).

Ruser, R., Flessa, H., Schilling, R., Beese, F., and Munch, J.C. (2001). Effects of crop-specific field management and N fertilization and N2O emissions from a fine-loamy soil. Nutrient Cycling in Agroecosystems,vol. 59,pp.177-191.

Saleemul, Huq (2008). Threats and opportunities. Ruser, R., Flessa, H., Schilling, R., Beese, F., and Munch, J.C. (2001). Effects of crop-specific field management and $\mathrm{N}$ fertilization and $\mathrm{N} 2 \mathrm{O}$ emissions from a fine-loamy soil, Nutrient Cycling in Agroecosystems, vol.59,pp.177-191.

Sandberg L. A., and Sandberg, T. (2010): Introduction: Climate change - who's carrying the burden? In: L. A. Sandberg and T. Sandberg (eds.), Climate change - who's carrying the burden? The chilly climates of the global environmental dilemma. Third volume in the Our Schools/Our Selves book series 2010.Ottawa, Canadian Centre for Policy Alternative

Scialabba, N. E., and Muller-Lindenlauf, M. (2010). Organic agriculture and climate change. Natural Management and Environment Department, Food and Agriculture Organization of the United Nations (FAO), Viale delle Terme di Caracalla, 00153 Rome, Italy. Renewable Agriculture and Food Systems, vol. 25 (2), pp.158-169 nadia.scialabba@fao.org.

Smith, K.A. and Conen, F. (2004). Impacts of land management on fluxes of trace greenhouse gases. Soil Use and Management, vol. 20, pp.255-263.

Smith, P., Martino, D., Cai, Y., Gwary, D., Janzen, J., Kumar, P., McCarl, B., Ogle, St., Howden, M., AcAllister, T., Pan, G., Romanenkov, V., Schneider, U., Towprayoon, S., Wattenbach, M., and Smith, J. (2008). Greenhouse gas mitigation in agriculture. Philosophical Transactions of the Royal Society B 363:789-813. 
Smith, P., Martino, D., Cai, Z., Gwary, D., Janzen, H., Kumar, P., McCarl, B., Ogle, S., O’Mara, F., Rice, C., Scholes, B., and Sirotenko, O.( 2007). Agriculture. In B. Metz, O.R. Davidson, P.R. Bosch, R. Dave, and L.A. Meyer (eds). Climate Change 2007: Mitigation. Contribution of Working Group III to the Fourth Assessment Report of the Intergovernmental Panel on Climate Change. Cambridge University Press, Cambridge, UK.

Spore, (2008). Crops weathering the changes. Climate change. Spore. Special Issue August, 2008. pp7-8. http:spore.cta.int

Steinfeld, H., Gerber, P., Wassenaar, T., Rosales, M., and de Haan, C. ( 2006). Livestock's Long Shadow: Environmental Issues and Options. FAO, Rome, Italy.

Uphoff, N. (2002). Changes and evolution in SRI methods. In N. Uphoff, E.C.M. Fernandes, L.P. Yuan, J.M. Peng, S. Rafaralahy, and J. Rabenandrasana (eds), Assessment of the System for Rice Intensification. Cornell International Institute for Food, Agriculture and Development, Ithaca, NY, USA. p. 8-14.

Van Diepen, P., McLean, B., and Frost, D. (2007). Livestock Breeds and Organic Farming Systems. ADAS Pwllpeiran and Organic Centre Wales, Aberystwyth, UK.

Yang, S.S. and Chang, H.L. (2001). Effect of green manure amendment and flooding on methane emission from paddy fields. Chemosphere-Global Change Science vol.3, pp.41-49. 